\title{
Combined Energy Supply for Sixty-Two Heliostats of the Big Solar Furnace
}

\author{
Akmaljon A. Kuchkarov*a, Shermuhammad A. Muminov \\ and Abdujabbar A. Abdurakhmanovb \\ ${ }^{a}$ Ferghana Polytechnic Institute \\ Ferghana, Uzbekistan \\ 'Institute of Material Science of SPA "Physics-Sun” AS RUz \\ Tashkent, Uzbekistan
}

Received 04.04.2020, received in revised form 15.04.2020, accepted 19.04.2020

Abstract. The article discusses the issues of increasing the reliability of regular, systematic, continuous operation during the day of 62 heliostats in the sun tracking mode by connecting to the centralized power network an additional autonomous power supply system with a power of $15 \mathrm{~kW}$, consisting of a standard gasoline engine with an inverter and a solar Fresnel mirror-concentrating system with a steam turbine generator that produces electric power.

Keywords: mirror concentrating systems, facets, module, concentrator, focus, inverter, steam turbine, generator, heliostat, automatic reserve input.

Citation: Kuchkarov A.A., Muminov Sh.A., Abdurakhmanov A.A. Combined energy supply for sixty-two heliostats of the Big Solar Furnace, J. Sib. Fed. Univ. Eng. \& Technol., 2020, 13(4), 449-454. DOI: 10.17516/1999-494X-0236

(C) Siberian Federal University. All rights reserved

This work is licensed under a Creative Commons Attribution-Non Commercial 4.0 International License (CC BY-NC 4.0).

* Corresponding author E-mail address: a.kuchkarov@ferpi.uz,ims-79@mail.ru 


\title{
Комбинированное энергообеспечение \\ 62 гелиостатов Болышой Солнечной Печи
}

\author{
А.А. Кучкаров ${ }^{\mathrm{a}}$, \\ Ш.А. Муминов ${ }^{a}$, А.А. Абдурахманов ${ }^{\sigma}$ \\ ${ }^{a}$ Ферганский политехнический институт \\ Узбекистан, Фергана \\ ${ }^{6}$ Институт материаловедения НПО \\ «Физика-Солние» $А$ Н РУ \\ Узбекистан, Ташкент
}

\begin{abstract}
Аннотащия. В статье рассмотрены вопросы обеспечения увеличения надежности регулярной, систематической, непрерывной работы в течение дня 62 гелиостатов в режиме слежения за Солнцем с помошью подключения в централизованную сеть электропитания дополнительной автономной электрической системы мощностью 15 кВт, состоящей из стандартного бензинового двигателя с инвертором и солнечной френелевской зеркально-концентрирующей системы с паротурбинным генератором, вырабатывающим электричество.
\end{abstract}

Ключевые слова: зеркальные концентрирующие системы, фацеты, модуль, концентратор, фокус, инвертор, паротурбина, генератор, гелиостат, автоматический ввод резерва.

Цитирование: Кучкаров, А.А. Комбинированное энергообеспечение 62 гелиостатов Большой Солнечной Печи / А.А. Кучкаров, Ш.А. Муминов, А.А. Абдурахманов // Журн. Сиб. федер. ун-та. Техника и технологии, 2020. 13(4). C. 449-454. DOI: $10.17516 / 1999-494 X-0236$

\section{Introduction}

The main purpose of the construction of the Big Solar Furnace (BSF) is to carry out work in a technological direction [1-3]. At the same time, technological work was related to the synthesis of hightemperature ultrapure materials or to the testing of materials and products of new technology for light resistance in the focal plane or near the focal region of a concentrator measuring $54 \times 47 \mathrm{~m}$ in paraboloid shape. The concentrator is illuminated by individual heliostats $7.5 \times 6.5 \mathrm{~m}$ in size with a total of 62 pcs [4-7]. The energy consumption of the heliostats is carried out from external centrally supplied electricity with a power of $\mathrm{W}=15 \mathrm{~kW}$ and $50 \mathrm{~Hz}$, which is converted to a frequency of $400 \mathrm{~Hz}$ using a specially designed electronic converter. Currently, difficulties arise with the continuous provision of an external three-phase power supply to the heliostatic field due to an unexpected irregular shutdown of the centralized power network.

\section{Material and methods}

In this paper, we consider the issues of continuous autonomous power supply of the heliostatic field using additional accumulating electrical energy from a system obtained from a gasoline generator, as well as connecting to the electricity generated by an autonomous linear Fresnel mirror concentrating system (LFMCS) with dimensions of 10x10 m, which converts the energy of the solar radiant flux into thermal saturated steam energy. Passing through a receiver of a tubular type, which is installed in the focal line of a Fresnel mirror with a heating temperature of up to $250 \div 300{ }^{\circ} \mathrm{C}$ and with a pressure of about 10 atm., steam rotates a special turbine with a current 


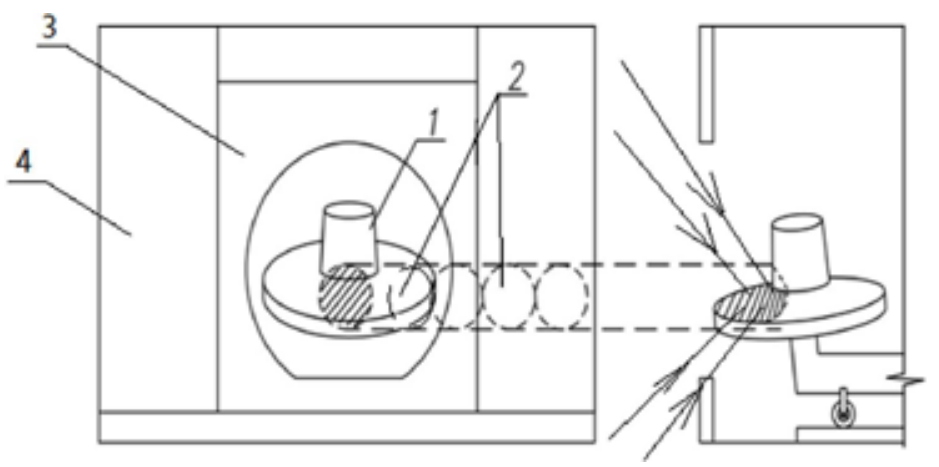

Fig. 1. The process of spot displacement in the focal plane when the heliostatic field power is turned off due to a change in the angle of solar radiation flux: 1 - hat-type furnace located in the focal plane; 2 - spot displacement when the heliostatic field is powered off; 3 - core water-cooled screen; 4 - cover of the tower

generator. The electricity generated by the generator enters the general energy supply system by the heliostatic field [8].

The event of an emergency shutdown of the central electric power supply to the heliostat field in the mode of regular continuous monitoring leads to the following undesirable phenomena (Fig. 1):

- quality deterioration of formed in the focal plane concentrated scattering spot of the radiant flux of the Sun due to its displacement.

- gradual shift of the scattering spot, causing a sharp increase in heat load due to the high values of the radiant flux concentration on the main screen (3) and the skin of the tower (4), which fail, that is, they can even melt.

\section{Technical solutions}

According to our proposed methodology, the BSF heliostatic field of a mirror concentrating system (MCS) will be powered by a separate additional autonomous electric station, which consists of an energy accumulator fed by various autonomously generating electrical energy systems, a block diagram of which is shown in Fig. 2.

Autonomous solar electric power supply for the BSF heliostat field using LFMCS with a steam generating system and a turbine (ASEP) consists of the following parts:

1. Solar Fresnel Mirror Concentrating System (SFMCS); 2. Accumulator of steam; 3. Turbine; 4. Generator; 5. Accumulator of heat carrier (water); 6. Electric pump; 7. Accumulation electricity system; CEP - The main centralized electric power supply of the gelostatic field of the BSF; AEP autonomous electric power supply using a standard commercially available gasoline engine with a current generator.

A solar power plant (SPP) based on LFMCS $10 \times 10 \mathrm{~m}$ in size allows to generate electrical and thermal energy up to $15 \mathrm{~kW}$ without negative impact on the environment.

The necessary provision of the total power for the heliostatic field with 62 heliostats with electricity is $\mathrm{W}=15 \mathrm{~kW}$ and $400 \mathrm{MHz}$. Our design of an autonomous Fresnel SPP based on a flat surface with an area of $S_{m}=10+10=100 \mathrm{~m}^{2}$ at a direct incident radiant flux density of the Sun $E_{c}=800 \mathrm{~W} / \mathrm{m}^{2}$ taking into account the specular reflection coefficient $R_{z}=0.7$ in the focal plane allows us to concentrate the power: 


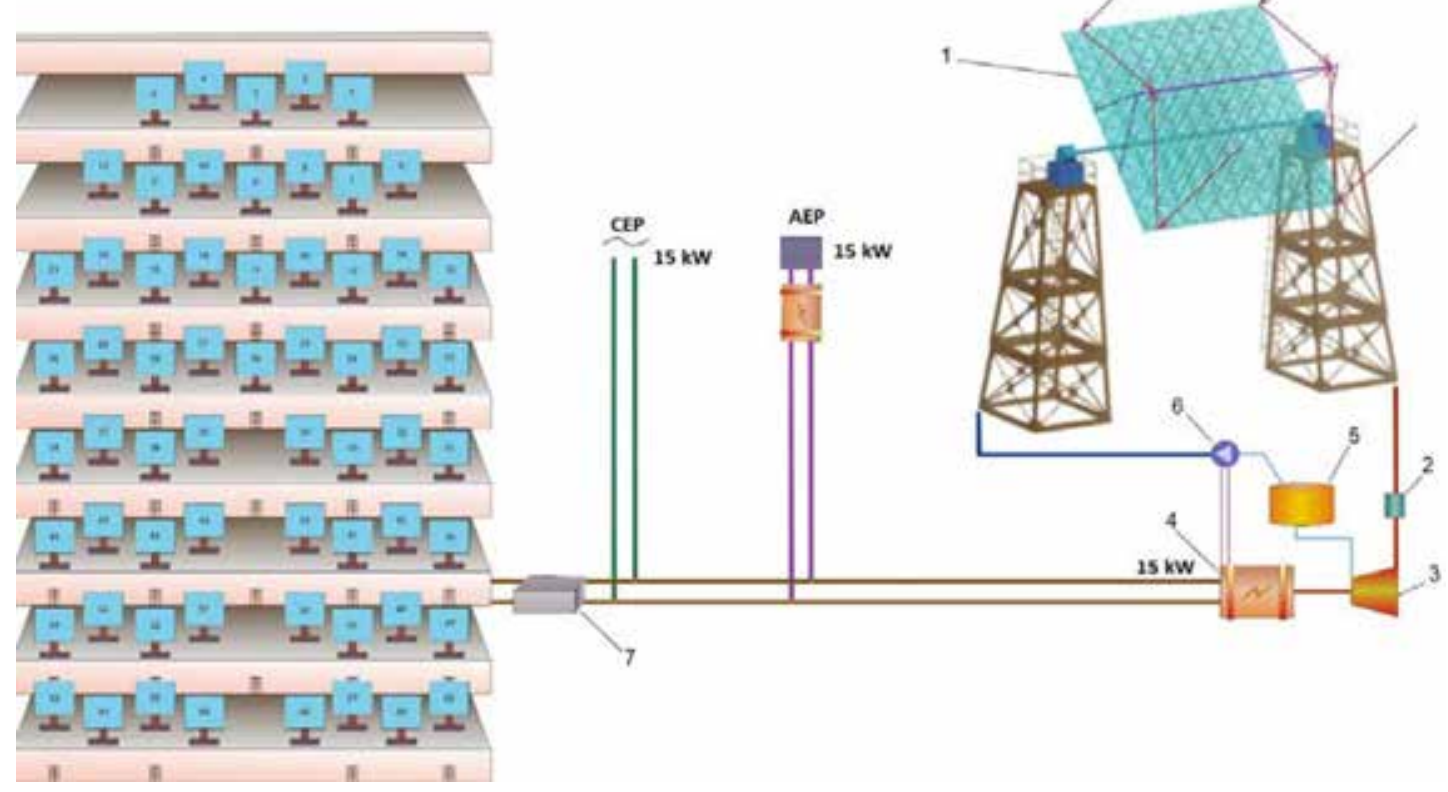

Fig. 2. Block diagram of combined autonomous power supply for the heliostatic field

$$
\mathrm{W}=\mathrm{R}_{\mathrm{z}} * \mathrm{E}_{\mathrm{c}} * \mathrm{~S}_{\mathrm{m}}=0.7 * 800 * 100=56 \mathrm{~kW} \text { of thermal energy. }
$$

Accounting for the conversion of radiant flux energy into electricity using a steam generator with a conversion factor of 0.35 is $19.6 \mathrm{~kW}$. The electricity received from the developed SPP is sufficient for autonomous operation of the mirror-concentrating BSP system without connecting an external power supply. The optical part of the station can be assembled from two types of MCS: parabolic or cylindrical.

The heat energy collected by MCS the working medium is high-temperature saturated steam water is pumped into the upper part of the storage tank, from where it can be taken to a steam generator, where high-pressure steam is generated for a steam turbine.

Low-temperature working water returns from the steam generator to the bottom of the main storage tank, and then to the heat pipe installed in the focal line in the MCS.

\section{Discussion results}

Studies show that an autonomous solar power plant based on the MCS at the focus of a concentrator measuring $10 \times 10 \mathrm{~m}$ with a focal length of $5 \mathrm{~m}$ at an aperture angle of $45^{\circ}$, where the temperature of the working fluid can reach a heating level of $300{ }^{\circ} \mathrm{C}$, has been developed and created at the moment [9]. One of the methods of uninterrupted voltage supply is the separate supply of the heliostatic field of the BSF with two independent sources of electricity, one of which is the main (working), and the second is reserve. The substation's operating line, which operates centrally, is used as the main source, and the second (backup) line consisting of an autonomous current and electricity generator generated by the steam generator complex with MCS is used as a backup source. The block diagram is shown in Fig. 2 .

One option for autonomous power supply is the use of a $15 \mathrm{~kW}$ gasoline generator. As a rule, all $15 \mathrm{~kW}$ gasoline generators are considered reserve and emergency, since they are needed for short-term 


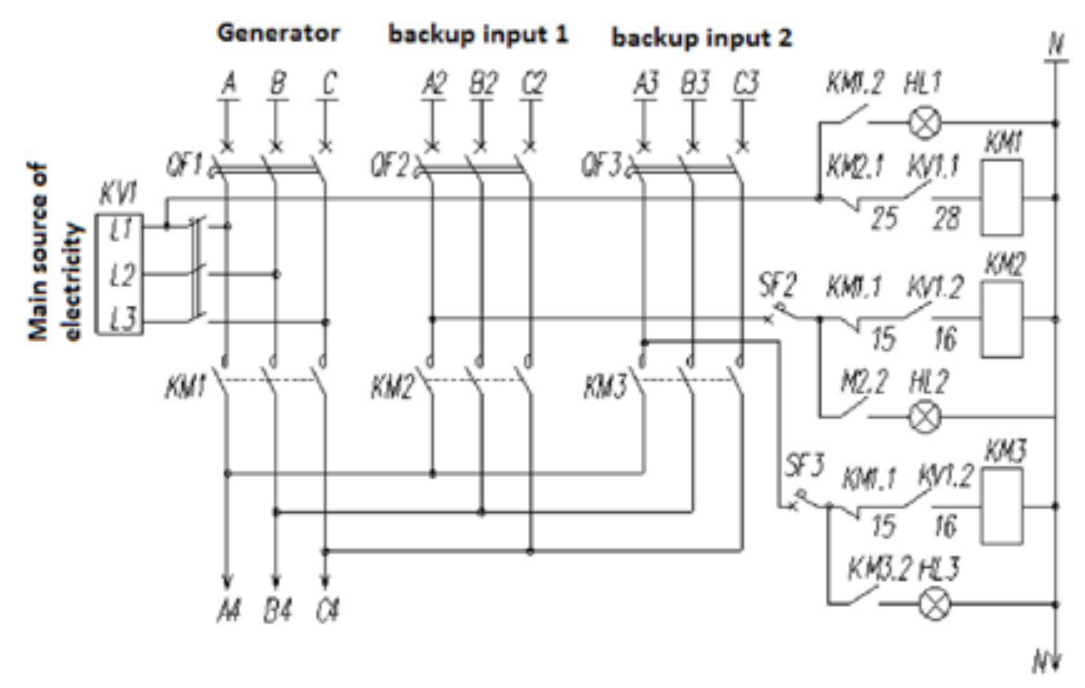

Fig. 3. Scheme of automatic reserve input

tasks, and not for constant power supply. The analysis shows that for the creation of autonomous power supply, the most suitable is a commercially available three-phase gasoline-powered generator type Zenith ZH16000 3DXE air-cooled [10]. The rated power of such a generator is $15 \mathrm{~kW}$, at a frequency of $400 \mathrm{~Hz}$ it consumes only 5 liters of gasoline per hour.

In an emergency, when the voltage disappears from the main power supply, it is important to ensure that the backup source is turned on quickly. For these purposes, an automatic reserve input (ARI) is used, which switches the voltage supply between the working and backup sources, providing a continuous supply of electricity to the heliostatic field of the MCS BSF.

In fact, the process of switching between the working and standby sources is important and includes a whole range of functions and parameters that ensure reliable operation of the ARI electronic system [11]. Therefore, at substations and distribution points of electric networks, complex multilevel ARI schemes are used, including the logical, measuring and power parts. In the framework of this technique, we considered only simple electrical circuits for automatic input of the reserve, performed on contactors, as well as the ARI circuit developed by us using a phase monitoring relay. All these schemes are easy to implement in an electrical network, and thereby provide uninterrupted power supply to the solar-field field independently.

\section{Conclusions}

Thus, the scheme of an autonomous power plant built according to the above principles has the following advantages:

- the possibility of inclusion in the composition of the generator (Zenith ZH16000 3DXE) or LFMCS with a steam generator;

- the availability of the software configuration of the energy storage system in an additional storage system of autonomous energy supply;

- the ability to effectively use the potential of the heliostatic field by installing additional modules for collecting information on environmental conditions and generating control actions for the 
autonomous control of the heliostatic field using the LFMCS with a steam turbine cycle or generator (Zenith ZH16000 3DXE).

\section{References}

[1] Azimov S.A. Research and Production Complex «Sun». Bi-mirror polyheliostatic solar furnace with a thermal power of $1000 \mathrm{~kW}$. Heliotekhnika, 1987, 7(6), 3.

[2] Riskiev T.T., Akbarov R.Yu., Abdurakhmanov A.A., Gulamov K.G., Yuldashev A.A. Operating experience of the Big Solar Furnace. Heliotekhnika, 1998, 1, 39-44.

[3] Rakhimov R.Kh. Big Solar Furnace. Computational-nanotechnology, 2019, 141-151.

[4] Abdurakhmanov A.A., Akbarov R.Yu., Saribaev A.S., Yuldashev A.A. Automated control system for the heliostat field of the Big Solar Furnace. Heliotekhnika, 1998, 1, 45-49.

[5] Akbarov R.Yu., Paizullakhanov M.S. Characteristic Features of the Energy Modes of a Large Solar Furnace with a Capacity of 1000 kW. Applied Solar Energy, 2018, 54, 99-109.

[6] Abdurakhmanov A.A. and et. Large Solar Furnace using for the astrophysical research. The fifth International Conference "Modern problems of nuclear physics". Book of abstracts, p. 53. Samarkand, 2003.

[7] Akbarov R. Thousand kW High-Temperature Solar Furnace in Parkent (Uzbekistan) Energetical Characteristics. Small-Scale Energy Harvesting, 2019, 6, 1-25.

[8] Kuchkarov A.A., Mamatkosimov M.A., Kholov Sh.R., Abdumuminov A.A. Autonomous power supply of 62 heliostats of the Big Solar Furnace of Megawatt power for technological purposes. Reports of the Academy of Sciences of the Republic of Uzbekistan, 2017, 1, 22-24.

[9] Kuchkarov A.A., Klychev Sh.I., Abdurakhmanov A. Power plant based onlinear with flat fresnel mirror facets. Computational nanotechnology, 2016, 2, 122-128.

[10]https://energybroker.ru/benzinovye-elektrostantsii-otkrytogo-ispolenija/43-benzinovyygenerator-zenith-zbs22000-3dxe.html

[11] https: //sesaga.ru/sxema-podklyucheniya-avr-na-kontaktorax-rele-kontrolya-2.html 